\title{
ORGANIZATION OF POLISH AND GERMAN HEALTH CARE SYSTEMS IN THE CONTEXT OF DRUG POLICY
}

\section{ORGANIZACJA SYSTEMÓW OCHRONY ZDROWIA W POLSCE I NIEMCZECH W KONTEKŚCIE POLITYKI LEKOWEJ}

\author{
${ }^{1}$ Health Care Department, Medical University of Warsaw \\ ${ }^{2}$ Public Health Department, Medical University of Warsaw \\ ${ }^{3}$ Public Health Department, Medical University of Warsaw
}

S u m m a r y

\begin{abstract}
Healthcare system in Germany is considered as one of the most effective systems all over Europe. Even in the face the ageing population, German healthcare is placed first in terms of the saturation in advanced medical technologies and access to medicinal products. Differences between the functioning of healthcare systems in Germany and other countries, such as Poland, are reflected by many epidemiological indicators.
\end{abstract}

The main purpose of that article is to present the differences in functioning the Polish and German systems, bearing in mind drug policy and regulations. In the article, there are presented some organizational and financing principles concerning healthcare systems in these countries as well as the healthcare expenditures structures.

\section{Streszczenie}

System opieki zdrowotnej w Niemczech uważany jest za jeden $\mathrm{z}$ najefektywniejszych systemów w całej Europie. Nawet w obliczu zjawiska starzenia się niemieckiej populacji, system wyróżnia się spośród innych stosowaniem zaawansowanych technologii medycznych czy szerokim dostępem do leków. Różnice pomiędzy funkcjonowaniem systemów ochrony zdrowia w Niemczech i innych krajach, np. w Polsce zauważyć można również, analizując różnego rodzaju wskaźniki epidemiologiczne.

Głównym celem artykułu jest zaprezentowanie różnic w funkcjonowaniu polskiego i niemieckiego system ochrony zdrowia, z uwzględnieniem polityki lekowej. W realizacji powyższego celu, w artykule scharakteryzowano m.in. organizację i zasady finansowania obu systemów, jak również porównano strukturę wydatków na zdrowie

Key words: Polish health system, German health system, organization and management in healthcare

Slowa kluczowe: system ochrony zdrowia w Polsce, system ochrony zdrowia w Niemczech, organizacja i zarządzanie opieką zdrowotną

\section{INTRODUCTION}

Healthcare in Germany is perceived to be one of the best systems in Europe. Currently, it can be observed that average life expectancy in Germany is increasing continuously. For many years average life expectancy in Germany has been one of the highest in the European Union and in the world [1]. Even in the face the ageing population, German healthcare is 
placed first in terms of the saturation in advanced medical technologies and access to medicinal products.

Differences between the functioning of healthcare systems in Poland and Germany are reflected by epidemiological indicators. Average life expectancy in Poland is estimated by OECD at 77 years and it is lower than the average in OECD countries (80 years). Average life expectancy in Germany is higher by one year than the average in OECD countries (average life expectancy in Germany is 81 years) [1]. Poland is characterised by a relatively low cancer prevalence rate in comparison with other European countries (1018.4 for men and 986.1 for women). In Germany these indicators are twice as high: 2100.5 for men and 1726.6 for women [2]. Another important indicator used to compare healthcare systems is 5-year survival rate for cancer. An analysis of available data shows that these indicators for Poland are $48.3 \%$ for women and $38.8 \%$ for men. In Germany 5-year survival rate for cancer is much higher: $58.8 \%$ for women and $50 \%$ for men [3].

\section{HEALTHCARE SYSTEM IN POLAND}

\section{Organization}

Management, funding, supervision and control in Polish healthcare system are divided between the Ministry of Health, National Health Fund (NHF) and local governments. NHFfunds healthcare benefits and signs contracts for these benefits with public and private healthcare providers. The Ministry of Health exercises supervision over NHF activities, whereas the Ministry of Finance supervises the Fund's financial activity. The Ministry of Health is also responsible for establishing health policy, funding and implementation of health programmes, funding of particular highly specialised healthcare benefits and major investments, scientific research and medical staff training. Moreover, it performs supervisory functions and direct managerial functions (with reference to some entities). At every level of administration local government is responsible for the identification of inhabitants' healthrelated needs, planning the supply of healthcare benefits and health promotion. For public healthcare centres established by a local government, the said government performs also certain functions connected with the management of healthcare centres' staff and investment funding, as well as supervisory and control functions [5].

\section{Healthcare financing rules}

Currently, approximately $98 \%$ of the population of Poland is covered by social healthcare insurance. Although this insurance provides a wide range of benefits, the participation of private healthcare expenditure in the total healthcare expenditure in Poland is higher than in most EU member states. This trend could be observed as early as the beginning of the 1990s when the participation of public funds started to decline clearly and in a short time (2000) direct household expenditure on healthcare (out-ofpocket payments, OOP) and reached the level of $30 \%$ of the total healthcare expenditure [7].

Social health insurance system funded by the NHF covers over $70 \%$ of current public healthcare expenditure. Other important public sources of healthcare funding are state budget and budgets of local government units.

Healthcare insurance contributions (current and past) constitute the biggest part of the NHF revenues. In 2009 the value of contributions increased by $6.5 \%$ in comparison with 2008; in 2010 it increased by $2.6 \%$ compared with 2009; and in 2011 the increase was $5.6 \%$ compared with 2010 [8] The remaining revenues are primarily revenues resulting from the regulations on the coordination of social security systems [9], and are related to medical benefits in kind performed for the citizens of the EU/EEA on the territory of the Republic of Poland.

\section{Healthcare expenditure structure}

General healthcare expenditure in Poland in 2011 amounted to PLN 105 billion (6.9\% of GDP) and consisted of current expenditure (approx. 93\%) and investment expenditure ( $7 \%$ of the total expenditure). Current public expenditure was PLN 69.2 billion and it constituted $4.5 \%$ of GDP (nominal value increase by $5.5 \%$ compared with 2010) [10].

NHF current expenditure, government and local government institutions constituted $70 \%$, whereas private expenditure constituted $29.1 \%$ of current expenditure (growth by $1.3 \%$ in comparison with 2010). Within the public sector NHF expenditure constituted $87.6 \%$, whereas the biggest stream of expenditure in the private sector came from households $(82.2 \%)$.

An analysis of particular functions of the healthcare system showed that in 2011 the biggest part of general expenditure was incurred on treatment and rehabilitation $(55 \%)$. The majority of expenditure on 
hospitalisation in Poland (97\%) is covered from public funds and only $3 \%$ from private funds [8]. In 2011 expenditure on medicines and medicinal products for outpatients constituted $25 \%$ of the total healthcare expenditure [10].

Considering the NHF expenditure on hospitalization in accordance with Diagnose Related Groups, the following medical interventions were the most expensive in 2009: labour and delivery (PLN 539.5 million), acute coronary syndromes (invasive treatmentabove 3 days - PLN 499.3 million; comprehensive invasive treatment- PLN 398.3 million), transluminal coronary angioplasty with Drug Eluting Stent (DES) implantation (PLN 373 million) and comprehensive treatment of stroke (PLN 356 million) [8].

It needs to be stressed that the system of copayment for health services is not common in Poland. It is introduced only in the case of reimbursement of medicines, medicinal products and aids, as well as in the case of health resort treatment benefitsand certain dental materials and treatments [5]. The biggest part of private healthcare expenditure in Poland is constituted by dental services (51.3\% in 2010), specialist services $(29.1 \%)$, outpatient and ancillary services $(7.7 \%)$ and primary healthcare services $(7.7 \%)$ [8].

\section{Access to medicines in the context of health insurance}

Every patient in Poland who has the right to healthcare benefits funded from the public funds, also has the right to the reimbursement of prescription-only medicines, foodstuffs intended for particular nutritional uses and medical devices [11].

General rules of reimbursement in Poland are determined in the Act of 12 May 2011 on the Reimbursement of Medicines, Foodstuffs Intended for Particular Nutritional Uses and Medical Devices. According to the provisions of the Reimbursement Act [13], medicines, foodstuffs intended for particular nutritional uses and medical devices specified in the announcements of the Ministry of Health are subject to reimbursement. Reimbursable medicines included in the reimbursement lists can be obtained for free or according to one of three payment schemes: lump sum payment (PLN 3.20), 30\% payment of the funding limit or $50 \%$ payment of the funding limit, whereby the funding limit is the maximum amount of money subsidised by the NHF to a given medicine.
Additionally, healthcare entities should provide inpatients with medicines which they should take due to their health condition. A patient who is discharged from hospital should be given by the doctor a prescription for medicines and a medical order for aids or medical devices which are orthopedic items listed on the medical order sheet [12].

The results of the research into healthcare expenditure in households show that expenditure on medicines and medicinal products have a very big share in the structure of general healthcare expenditure as in 2010 it constituted over $64 \%$ of the average monthly healthcare expenditure per capita, and it amounted to PLN 33.7. Moreover, the level of this expenditure was much higher in urban areas than in the rural ones, and even higher in cities. Over $90 \%$ of households bought prescribed medicines, nearly $44 \%$ bought medicines which were recommended but not prescribed by a doctor, and simultaneously $88.7 \%$ of households bought medicines on their own initiative. At that time households spent monthly PLN 3.1 per capita on average on durable medical equipment (e.g. eyeglasses, prosthesis, contact lenses, wheelchairs) [8].

\section{HEALTHCARE SYSTEM IN GERMANY}

\section{Organization}

Healthcare system in Germany is based on four subjects where German Health Fund (Gesundheitsfonds) is the primary subject. The second subject is statutory health funds, the third one healthcare providers (doctor and hospitals) and the fourth one - 70 million patients (approx. 90\% of German society; the remaining $10 \%$ of citizens have private healthcare insurance) [14].

German healthcare system is decentralized and based on self-governing structure: health funds, health fund associations, medical chambers, health fund doctors associations, hospital associations and other healthcare providers unions. These institutions are public law entities and they operate non-profit [15].

German citizens have the right to choose between two types of healthcare insurance. Statutory healthcare insurance (Gesetzliche Krankenversicherung, GKV) is organised by the state. The state defines the rules of healthcare system functioning and funding through appropriate legal provisions which guarantee that patients obtain necessary health services at the highest level of accessible medical knowledge [14]. Optionally, there is a possibility to choose a private 
healthcare insurance (Private Krankenversicherung, PKV) which is dedicated, first and foremost, to the self-employed, representatives of liberal professions (lawyers, doctors, etc.) and clerks. Those employed on the basis of an employment contract can also join a private health insurer but only if they earn more than EUR 53,550 gross annually [16].

Healthcare system in Germany is financed mostly from two sources. Patients' healthcare contributions are the first source of funding and - similarly to taxes are collected centrally by the Health Fund and then transferred to health funds.

The other source of funding is the state budget. The amount of contributions is $14.9 \%$ of the gross income of an insured person. This contribution depends solely on the insured person's income and is paid to the statutory health fund. Thus, this is not the type of insurance where the contribution depends on, e.g. age, gender and health condition (as in the case of private health insurance). The legislator defined the upper income limit (Bemessungsgrenze), from which the collected contribution is paid to the statutory health insurance - in 2010 it was EUR 3,750 monthly; that is EUR 45,000 annually. Patients who earn more, do not pay health insurance contribution for the part of income which exceeds the income limit [14].

\section{Healthcare financing rules}

The currently binding funding of healthcare system in Germany was introduced in an act on obligatory sickness insurance which entered into force on 1 January 2007. Ever since every German citizen is subject to obligatory sickness insurance. This insurance can be taken out at a statutory health fund or at a private health insurer [14].

Healthcare in Germany is funded from diversified sources: obligatory health insurance, state budget, voluntary insurance and direct payments made by patients. About $13 \%$ of German citizens have private health insurance. Out-of-pocket funding in Germany is rare (only 9\%) and it refers only to the richest patients who did not decide to take out any insurance.

Hospitals, both public and private, are taken into account in plans which are drawn by a state and they are funded in a double system. General costs are covered by a state (Land), whereas operational costs are covered by health funds and by hospitals. In hospital sector there are three types of hospitals: public, non profit, and private for profit [17].
According to the Federal Statistical Office, total costs of healthcare system funding in Germany in 2008, including costs of benefits and medicines, amounted to EUR 263,2 billion [14].

\section{Healthcare expenditure structure}

The level of expenditure on healthcare in Germany is one of the highest in all EU countries. Total expenditure on healthcare in 2012 amounted to $11.3 \%$ of GDP, which is equivalent to USD 320662 million in purchasing power parity. In comparison with the year 2000, total expenditure on healthcare increased by $0.9 \%$ GDP. Healthcare expenditure per capita in 2012 amounted to USD 4811 and increased by USD 2130 compared with the year 2000. Expenditure on medicines per capita in 2012 amounted to USD 668 and constituted $14.4 \%$ of the total healthcare expenditure in Germany. Public expenditure in German healthcare system amounts to $76.7 \%$, whereas out-ofpocket payments constitute $13 \%$ [18]. To sum up, participation of GDP in healthcare expenditure in Germany is $11.3 \%$. Due to high expenditure, good investments in healthcare sector and very good access to health services, average life expectancy in Germany is almost 81 years and therefore, according to the latest WHO report, German healthcare system ranks at the $25^{\text {th }}$ place in the world [19].

\section{Access to medicines in the context of health insurance}

In Germany there are mechanisms of control over treatment's effectiveness and reduction of expenditure on the reimbursement of medicines by public health insurance funds. The Federal Joint Committee (Gemeinsamer Bundesausschuss, GBA) is a body with broad competences in this respect. It is supervised by the Ministry of Health and consists of the representatives of organizations which represent public health insurance funds, health fund doctors and hospitals. GBA is supported by the Institute for Quality and Efficiency in Healthcare (Institut für Qualität und Wirtschaftlichkeit im Gesundheitwesen) which verifies cost- effectiveness of a medicine on the basis of the following criteria: improvement of a patient's health condition, elimination of unwanted adverse reactions, shortening of the duration of an illness, increasing the average life expectancy and improvement of living standard [20].

German healthcare system allows payment for prescription-only medicines in the amount of $10 \%$ of 
the price; however, this payment cannot be lower than EUR 5 or higher than EUR 10. This payment does not refer to children and teenagers under 18 and to pregnant women. It is every patient's obligation to present required documents. If this obligation is not complied with, full costs of treatment are to be charged, and prescribed medicines are to be paid in full. In this case reimbursement system is to be cancelled [21].

A patient who is subject to hospital treatment obtains necessary medicinal products within the framework of health insurance. Payment for medicines is settled with the health insurance payer by means of Diagnose Related Groups (DRG) system.

\section{SUMMARY}

German healthcare is considered to be one of the best (although at the same time the most expensive) in the world. An extensive network of hospitals and medical services reach even the most remote corners of the country. Waiting lists for treatments are rare. Medical centres have cutting-edge equipment, and basic insurance provides almost full reimbursement of treatment and medicines. Nearly all German citizens have access to the system, regardless of their income or social status. However, it can be argued that medical costs are very high. Charges for healthcare - doctors' services, hospital stays and even medicines - are among the highest in the world. There is no 'free treatment', even in state hospitals. Each type of care, even first aid, is paid for by the patient or from his insurance. Healthcare in Germany is characterised by a very high availability. This is due to an extensive network of hospital facilities. Motivators, such as a charge for open healthcare services and a one-day hospital stay charge, stimulate huge supply of outpatient services and encourage long hospital stays. Healthcare expenditure is $10.5 \%$ in relation to GDP, which places Germany second in the world after the United States.

The fact that the number of citizens of Germany is twice bigger than in Poland explains why the value of German GDP (USD 3,414 billion) and total healthcare expenditure (EUR 253 trillion) are much higher [18]. Healthcare funding in Germany is more than 12 times higher than in Poland, which results in greater availability of higher standard services or more modern medical equipment. Moreover, healthcare expenditure per capita in Germany is three times higher than in
Poland, as the result of which patients are 'pampered', to put it colloquially, in terms of healthcare, and thus, they are more demanding, which creates the necessity of healthy competition that helps to raise standards of treatment and improve healthcare for every patient in Germany. Unfortunately, in Poland an opposite situation can be observed. Here a patient often has to specifically address staff in a medical centre in order to be treated well and with respect.

\section{REFERENCES}

1. OECD data, http://www.oecd.org/health/, [access: 12.09.2014].

2. European Cancer Observatory data, http://eco.iarc.fr/, [access: 12.09.2014].

3. Ferlay $\mathbf{J}$, et al. Estimates of cancer incidence and mortality in Europe in 2008. Eur J Cancer 2010 Mar;46(4):765-81.

4. CDC data, http://www.cdc.gov/nchs/data/databriefs/ db23.pdf, [access: 12.09.2014]

5. Outline of the health care system - POLAND 2012 National Health Fund, European Observatory on Health Systems and Policies, Warsaw 2012

6. The Act of 23 January 2003. On general insurance in the National Health Fund, OJ 2003 No. 45, item. 391.

7. Sobczak A, Polish health care system rating, akademia.nfz.gov.pl, [access: 12.09.2014].

8. The Polish population health and its determinants, Wojtyniak G Goryński P Moskalewicz B (ed.), National Institute of Public Health - National Institute of Hygiene, Warsaw 2012.

9. Regulation of the European Parliament and Council Regulation (EC) No 883/2004 of 29 April 2004 on the coordination of social security systems (L 166 of 30 April 2004 as amended.).

10. Central Statistical Office, National Health Account for the year 2011

11. The health care benefits financed from public funds, Tyszko R (ed.), National Health Fund, Warsaw 2012.

12. Council Directive of 21 December 1988. Relating to the transparency of measures regulating the pricing of medicinal products for human use and their inclusion in the scope of national health insurance systems (89/105/EEC).

13. The Act of 12 May 2011. For reimbursement of medicines, foodstuffs intended for particular nutritional and medical devices, OJ 2011 No. 122, item. 696, as amended.

14. Financing of the German Healthcare System, Office of the Senate, Office of Research and Documentation, Department of Analysis and Thematic Studies, Warsaw 2010.

15. The report summarizing the assessment of substantive projects with the health sector in order to select a pilot project for implementation in the form of a public-private platform Public-Private Partnership, Warsaw 2013. 
16. http://www.arbeitsgemeinschaft-privatekrankenversicherung.org/pkv-

versicherungspflichtgrenze-fuer-2014-auf-53-550-euroerhoeht/ [access: 05.09.2014].

17. Hibner E, management in the health system, Lodz 2003.

18. http://www.oecd.org/els/health-systems/Briefing-NoteGERMANY-2014.pdf [access: 09.05.2014].

19. The world health report 2000 - Health systems: Improving performance, WHO, Geneva. 2000.

20. http://www.rynekzdrowia.pl/Rynek-Zdrowia/Niemcy-iWlochy-dwa-rozne-modele-refundacji-lekow,51647.html [access: 05.09.2014].

21. http://www.nfzszczecin.pl/leki_w_panstwach_ueefta.htm 05.09.2014].
Address for correspondence:

Urszula Religioni, MSc

Medical University of Warsaw

Public HealthDepartment

Head of the Department

Adam Fronczak, Associate Prof.

1a Banacha St.

02-097 Warsaw

tel.: (0-22) 5992180

e-mail: urszula.religioni@gmail.com

[access:

Received: 12.11.2014

Accepted for publication: 17.03.2015 